\title{
口腔内帯状疮疹と神経支配
}

\author{
戸島均・稲村 博雄・青柳 優・小池 吉郎
}

\section{Herpes Zoster in the Oral Cavity}

\author{
Hitoshi Tojima, Hiroo Inamura, Masaru Aoyagi and Yoshio Koike \\ (Yamagata University)
}

Six cases of herpes zoster in the oral cavity are reported. Three cases were affected with severe facial palsy (Hunt syndrome), and the other 3 were trigeminal herpes without facial weakness. Localization of symptoms and lesions was limitted within the distribution of each branch of the nerve on the affected side. Especially, in the cases of facial palsy, vesicular eruptions or erosins overlying only the soft palate (greater petrosal nerve area) and/or anterior two-thirds of tongue (chorda tympani area) were observed. Acyclovir greately reduced the pain and shortened the illness. But this drug was not effective on nerve disturbances, especially on the loss of tasts in the 3 patients with Hunt syndrome.

Key words: herpes zoster, oral cavity, trigeminal nerve, facial nerve, Hunt syndrome

一般に帯状疮疹は, 知覚神経節に潜伏感染し ている帯状疱疹ヴィルスの再活性化により，そ の神経支配領域の皮䖉や粘膜に出現する。腔 内には温痛覚を司る三叉神経と，舌前 $2 / 3$ と軟 口蓋の味覚を司る顔面神経が分布している.我 々は最近経験した口腔内帯状疮疹 6 例の内, 明 かに顔面神経支配領域の帯状疱疹 (Hunt 症候 群） 3 例と三叉神経領域の帯状疱疹 3 例を呈示 し, その特徴と随伴する神経障害, 治療に伴う 帯状疮疹, 神経症状の推移について報告する.

\section{症例}

症例 $1 ： 56$ 歳女性, 既往歴に胃潰瘍あり。口 内痛, めまい, 左耳鳴とともに左顔面神経麻痺 が発症した. 図 1 のよらに左顔面神経麻痺を認 めるが, 耳介帯状疮疹は無く, 豉膜は正常であ る. 発症 3 日の口腔内所見は, 左軟口蓋粘膜と
左舌前 $2 / 3$ 粘膜に多発融合した水疮がみられた （図 2 ）。検查所見では左軽度感音難聴，左半規 管麻痺を伴い，アブミ骨筋反射の消失，味覚検 查にて味覚消失を認めた。 ステロイド大量療法 とともにアシクロヴィルを点滴静注したところ， 発症10日で口腔内帯状疱疹の消失, 難聴の正常 化が観察されたが，顔面神経麻痺は完全脱神経 となった．発症 6 月では，顔面運動は36点（顔 面運動採点40点法）まで回復したが病的共同運 動が出現した．アブミ骨反射は正常化したが， 味覚障害は 2 年 6 力月後も残存し, 左口腔内が 食事中渋い感じがすると訴えている。

症例 $2 ： 49$ 歳女性，既往歴に特記すべき事な し. 右顔面神経麻痺発症第 3 日よりステロイド 大量療法開始, 第 5 日に激しい口内痛が出現, 経口摂取できなくなった，開口させると口臭あ 
り, 右軟口蓋に限局した水疱形成をみた（図 3 ). 口腔内帯状疱疹と診断，アンクロヴィルを点滴 併用したところ, 口内痛は速やかに消失, 水疱 は融合し 1 週で糜㯗となり, その後, 治癒した。 右外耳に所見なく, 聴力, 平衡機能は正常であ った. 右顔面神経麻㽻は重症で ENoG (Electroneurography）最低值は $2 \%$ で，味覚脱出， 涙分泌抑制を認め，アブミ骨筋反射は消失して いた. 6 力月までに涙分泌，アブミ骨筋反射は 回復したが，顔面運動は 30 点（40点満点法）ま でしか回復せず，1 年11力月では病的共同運動 が認められ，味覚障害は残存した。

症例 3 : 66歳男性, 既往歴に特記すべき事な し. 口内痛とともに右顔面神経麻疩発症，第 7 日の所見では，耳介，外耳道は正常であるが， 患側軟口蓋に多発する糜爛を認めた（図 4 ）。 カロリックテストで右半規管麻痺を認めたが， 聴力に左右差はなかった。アブミ骨筋反射消失, 味覚検査で患側の味覚障害あり。ステロイド大 量療法とともにアシクロヴィルを点滴併用した。 顔面神経麻痺は重症で強い脱神経 (ENoG $5 \%$ )

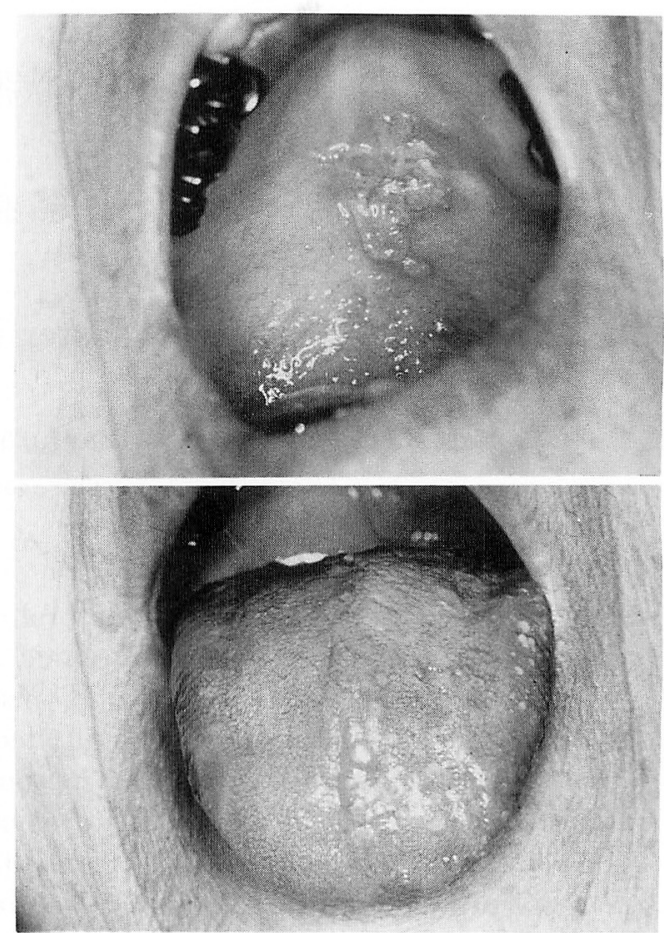

図 2 症例 1

左軟口蓋（図上）と左舌前 $2 / 3$ （図下）の粘膜に 限局した融合水泡（顔面神経麻㽻発症第 3 日）。

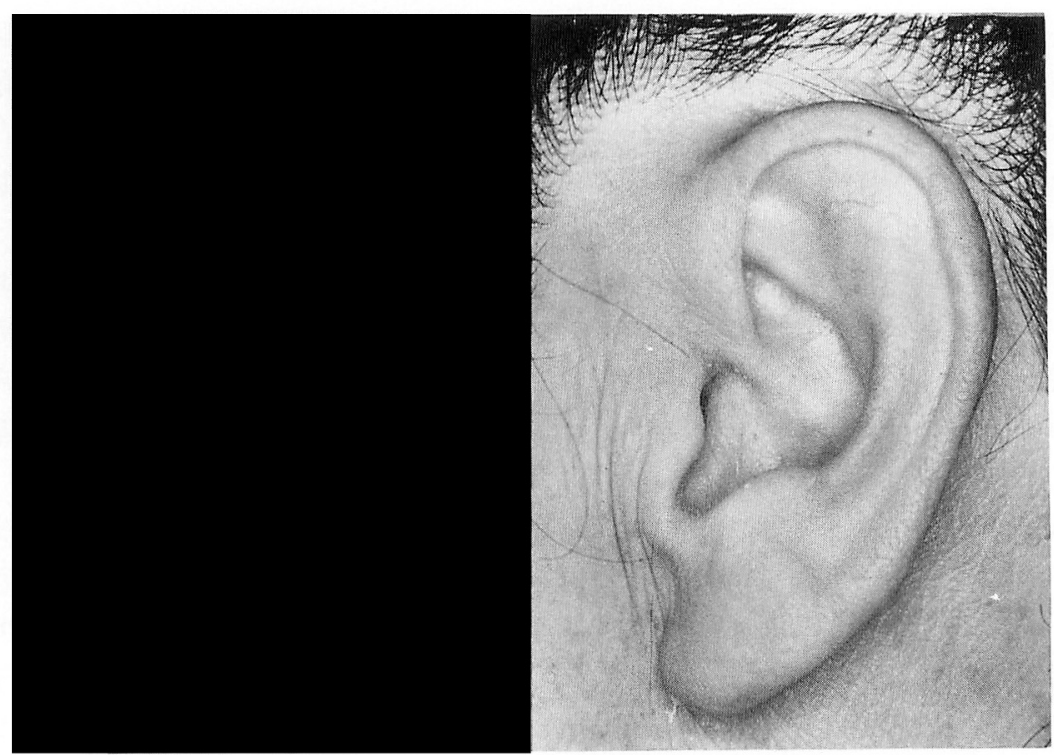

図 1 症例 1 56歳女性 左顔面神経麻㽻と正常な耳介 
となったが，2 年 2 力月後には病的共同運動を 軽度伴らものの, 顔面運動は38点まで回復した。 しかし，味覚異常は続さ，自覚症状として患側
口腔内のにがみを訴えている。

症例 4 : 60歳女性，庇往歴に特記すべき事な

し. 左三叉神経第三枝領域の帯状疱疹のため,

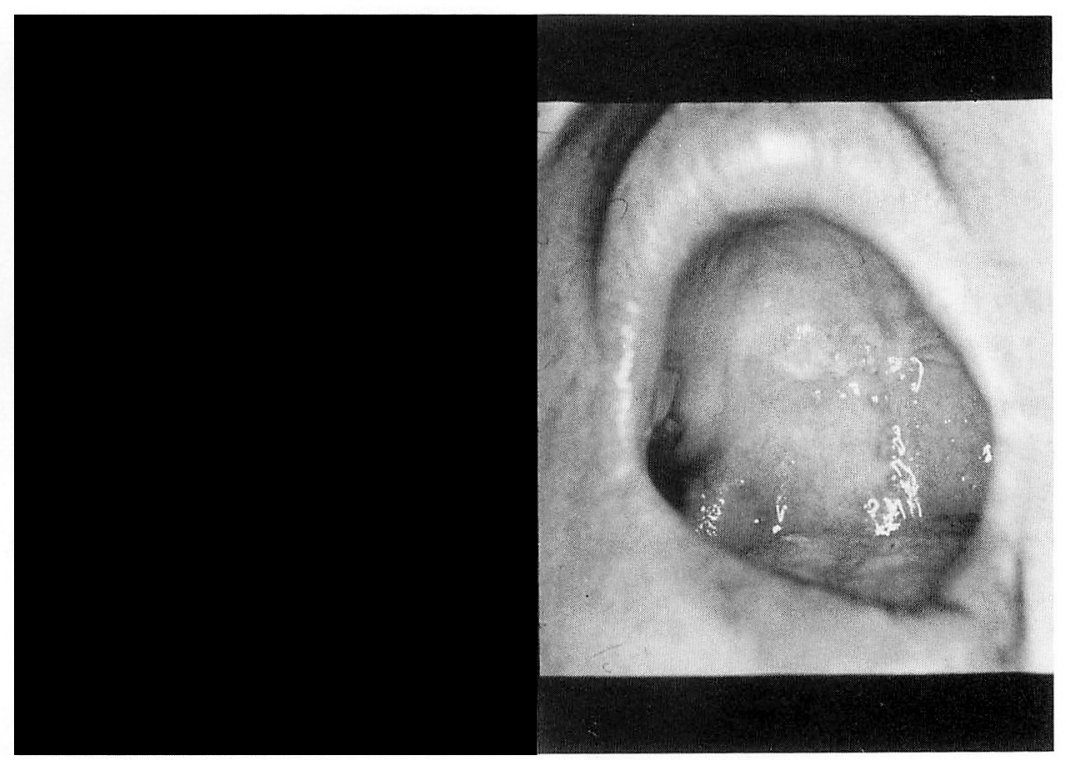

図 3 症例 2 49歳女性

右顔面神経麻痺と右軟口蓋の水疮（顔面神経麻㽻発症第 5 日，口内痛発症第 2 日）.

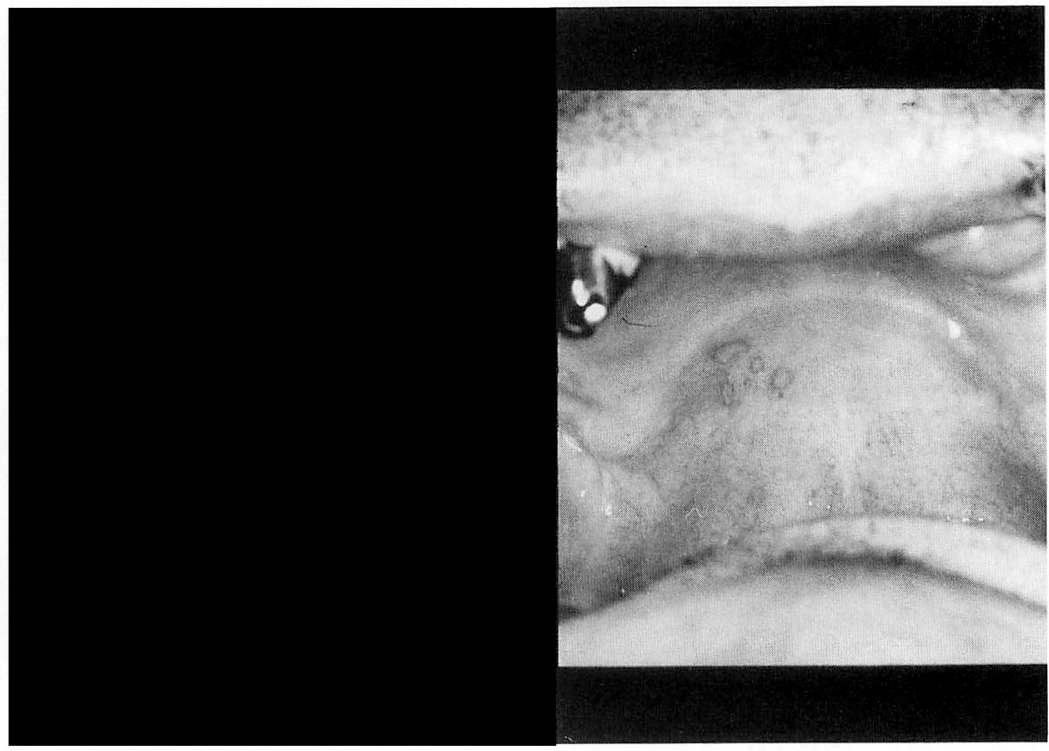

図 4 症例 3 66歳男性

右顔面神経麻㽻と右軟口蓋の多発する糜爛（発症第 8 日）。 
発症第 3 日に入院となった. 三叉神経第三枝領 域の顔面皮膚に融合した水疱とともに，口腔内 には舌左半分と口唇粘膜, 頓粘膜に同様の水疱 が出現していた（図５）。味覚障害はなく，聴 神経，顔面神経は異常なかった。アシクロヴィ ルの点滴により, 疼痛が速やかに消失するとと もに，顔面皮膚の水疱は痂皮を形成した， 口腔 内の水疮は融合する糜爛となり，痂皮を形成す る事なく治癒した。全経過は 2 週間で後遺症は なかった。

症例 5：63歳女性，既往歴に特記すべき事な し. 右口内と下顎の疼痛にて発症第10日に受診 しだ．顔面皮膚右三叉神経領域の痂皮（図 6 ） と口腔内の舌右半, 口唇粘膜の糜爛（図 7 ）が 認められた。味覚は正常で経口摂取は可能であ り，鎮痛剤にて疼痛の軽減が認められたため外 来で加療，その後 8 日で，神経障害をきたすこ

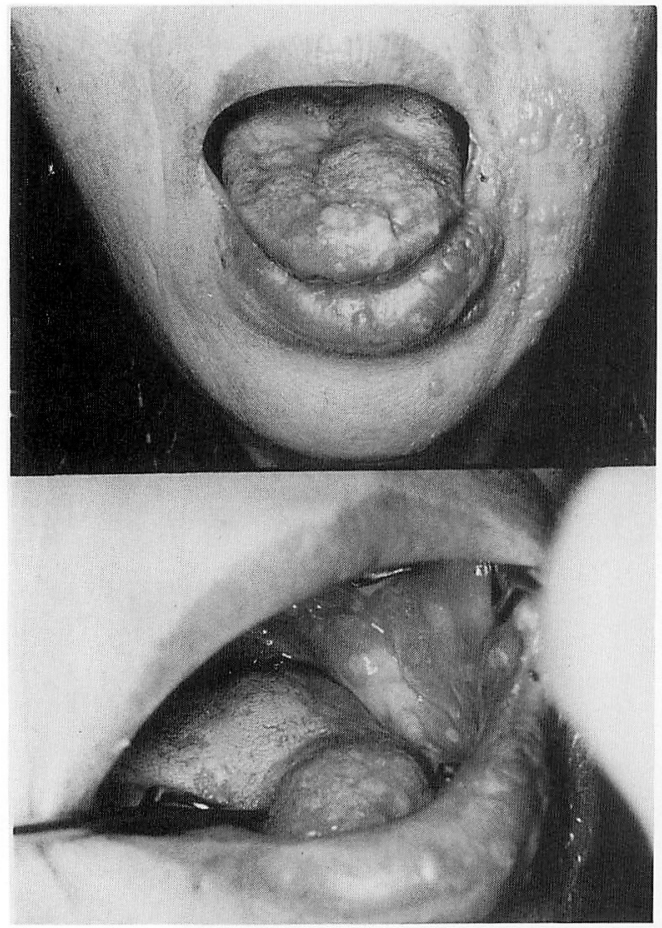

図 5 症例 4 60歳女性

左三叉神経第三枝領域の皮虏帯状疮疹と舌前 $2 / 3$ 之頓粘膜の水疮形成した带状疮疹（発症第 3 日）.
となく治癒した。

症例 6 : 71歳女性, 右三叉神経第二, 三枝領 域の帯状疮疹にて麻酔科入院となった患者第 8

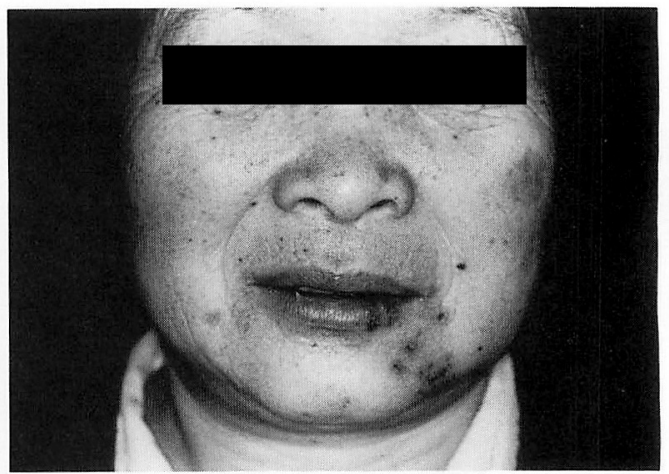

図 6 症例 5 60歳女性 右三叉神経第三枝領域の帯状疮疹痂皮形成（発症 第10日)。
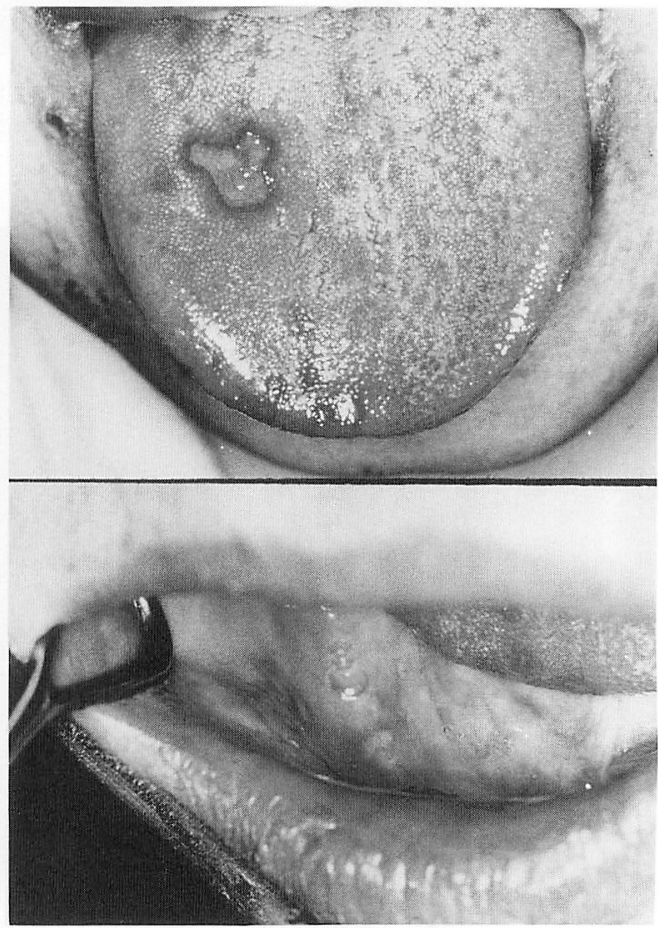

図 7 症例 5

舌から口唇, 頉粘膜にいたる多発する不整形の糜 爛（発症第10日）。 
病日であるが，口蓋粘膜の右半から右煩粘膜に かけて融合した糜閑となっていた，糜爛は硬口 蓋を含めた口蓋全体に及ぶが，反対側つまり健 側には全く及ばず，境界線は口蓋正中線となっ ていた（図８）。味覚を含めた顔面神経障害は 認められず，聴力の左右差はなかった．著しい 疼痛あるも，麻酔科にて星状神経節ブロックな どの治療を行った。

\section{考察}

口腔内帯状疱疹について我が国内での報告は 三叉神経領域の帯状疮疹症例報告が多(1) 3), 成書でも記載のないものが多い。また，あった としても簡単な記載にとどまり4) 6)，まと末っ た論文は洼とんどない。また，顔面神経麻㽻を 伴った口腔内水疮や帯状疱疹の詳細な記載も少 な(、7) 9). 今回我々は，口腔内帯状疮疹の臨床 的特徵を記載するとともに，顔面神経領域に発 生した症例を三叉神経に発生した場合と比較し， その違いを明確に示して，随伴した神経障害に ついても考察を加光る。

口腔内帯状疮疹は一側口腔粘膜の水疮の出現
で始まる，著しい疼痛があり, 摂食障害, 口臭 がある場合が多いが, 症例 5 のように比較的軽 度の場合も政。水疮は必ず一側であり, 反対 側すなわち健側には絶対及ばない。これは知覚 神経支配が反対側には及ばないためであり，典 型的な症例 6 のように境界は正中線上に一致す る. 水疱は融合し（図 $2,3,5$ ), その後白苔 を伴った浅い潰瘍か糜爛となる（図 4,7,8）. この,「一側性」で「融合」するという2 点は 他疾患と鑑別診断を行ら上で重要である。たと 壳ば，似たよらな口腔内病変を形成するへルパ ソギーナ（コクサッキーヴィルス感染症）など は，一側にはとどまらず両側に広がる事が多い し，アフタ性口内炎は境界明瞭で融合すること は注とんどない。他の, 単純へルペス感染, 風 疹，手足口病などのヴィルス性感染症はこの 2 点と発症年齢に注意すればおおおと鑑別可能で ある。また，皮膚の帯状疮疹と異なり治癒過程 に扮いて痂皮を形成しないのが 6 例の共通した 所見であった。

帯状疱疹は知覚神経節に潜伏感染した水痘帯

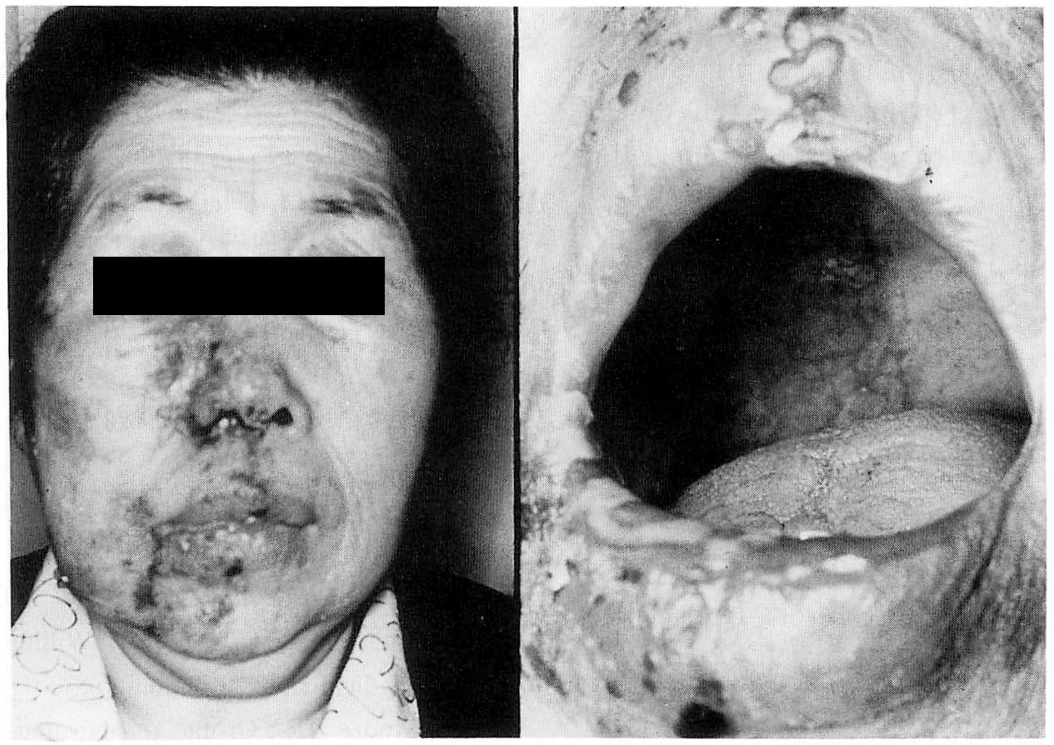

図 8 症例 6 71歳女性

右三叉神経第二枝，三枝の顔面皮䖉帯状疮疹と， 口腔内の右半口蓋粘膜から煩粘膜に広がった多発 融合不整形の糜爛で，境界は正中線上にある（発症第 8 日）. 
状疮疹ヴィルスが再活性化して起こるとされて いる. 口腔内の知覚神経の内, 三叉神経節から の第二, 三枝が広く口腔粘膜の温痛覚, 触覚を 司っている. 顔面神経は膝状神経節から分かれ た大錐体神経が軟口蓋の味覚を, 豉索神経が舌 前 $2 / 3$ の味覚を支配する. 帯状疮疹の出現した 口腔粘膜の範囲によりその再感染した原因神経 を推定できる. 症例 1 から 3 までは末梢性顔面 神経麻疩と同側の口腔内帯状疮疹を伴った症例 であり，膝状神経節に抢けるヴィルス再活性化 と考兄られる.これらの口腔内帯状疱疹の発生 部位の特徴は患側の軟口蓋または舌前 $2 / 3$ の粘 膜に限局している。一方, 三叉神経領域の帯状 疱疹は，舌から煩粘膜に及び，かつ軟口蓋の及 ならず硬口蓋にも病変が広がっている. 帯状疱 疹の発生部位は解剖学的神経支配を忠実に反映 しているのが判る. 顔面神経麻痺は三叉神経領 域の帯状疮疹のみならず頸部の帯状疮疹でも来 たし得るので, 顔面神経麻痺があるからといっ て顔面神経領域の帯状疮疹とは言えない。帯状 疱疹の出現部位が原因神経を推定しうる唯一の 根拠である。

顔面神経領域の帯状疱疹に合併した顔面神経 麻痺は Hunt 症候群の範疇に入るが， 3 症例と も耳介や外耳道には帯状疮疹は無かった。 通常 の Hunt 症候群は, 耳介の geniculate zone と 呼ばれる顔面神経の知覚支配領域に帯状疱疹が できる場合がほとんどである，今回経験した口 腔内の帯状疱疹に伴う Hunt 症候群 3 症例の味 覚障害は, 重症で永続的であった。これは通常 経験するHunt 症候群よりも, 味蕾や味覚神経 への直接的な炎症性障害が強いためではないか と考えている.

帯状疮疹の治療には抗ヴィルス剤, 特にアシ クロヴィルが有効である。我々は Hunt 症候群 に対し, Bell 麻痺に対する保存的治療法（ステ ロイド大量療法) 10) に加えアシクロヴィルを点 滴併用寸る治療法 1112) を行ってきた。一般に Hunt 症候群の顔面神経麻痺はBell 麻㿁より重 症である。ステロイド大量療法にアシクロヴィ
ルを併用しても顔面神経麻痺の治瘉率は重症例 で60\%程度であり, Bell 麻痺重症例に抢けるス テロイド大量療法の治瘉率 $96 \%$ よりかなり悪い. 今回報告した Hunt 症候群の 3 症例とも顔面運 動はかなり回復したが後遺症を残し不完全回復 であった。アシクロヴィルは帯状疮疹の治癒過 程を早め, 疼痛の軽減には有効である。しかし, 顔面神経麻痺のような随伴する脳神経障害への 効果は期待できるものではなさそうである.

以上, 口腔内帯状疮疹 6 症例を報告し，その 口腔内所見の特徵と随伴する神経障害に関して 考察した. 今回の 6 症例は, 帯状疱疹の出現部 位や神経障害などから原因となる神経は明らか である.今後顔面皮膚に帯状疮疹が伴わなかっ たり，顔面神経麻㽻などの神経障害が無い場合 でも，本論文で述べた特徵的な臨床所見に注意 すれば口腔内帯状疮疹の診断は可能であろら.

\section{まとめ}

口腔内帯状疮疹 6 例について，その口腔所見 の特徵, 臨床経過について記載し, 原因神経の 推定方法ついて検討した.

\section{文 献}

1）本多善孝, 天笠 稳, 松田 昇: ヘルペス性歯 肉炎拉よびロ腔内に症状を呈した帯状疮疹の臨 床ならびに病理学的, 電顕的検討. 日口外誌 $36: 1528 \sim 1537,1990$.

2) 大久保章朗, 向井 洋, 川島清美, 他: 最近経 験した帯状疮疹の 3 例. 日口外誌 $34: 973 \sim 979$, 1988.

3）山口好則, 川崎傳夫, 飯田正人, 他：7藏男子 の三叉神経第二枝, 第三枝に発生した帯状疱疹 の 1 治検例. 日口外誌 $28: 1560 \sim 1564,1982$.

4）毛利 学: 口腔内病変. 図説耳鼻咽喉科講座第 4 卷口腔, 咽頭, 喉頭, 食道疾患. $14 \sim 15$ 頁, 1983.

5) Cawson RA and Eveson JW : Oral pathology and diagnosis. 11.5, William heinemann Medical Book, London, 1987.

6) Moore JR : Orofacial neuropathology. Surgery of the mouth and jaws. pp 797 823, Blackwell Scientific Publications, London, 1985.

7）小池吉郎, 戸島 均 : Ramsay Hunt症候群に 
伴ら疼痛について. 耳喉頭頸 61: 929 932, 1989.

8）柳原尚明：口蓋の水疮. 側頭骨内顔面神経麻㽻 病態と治療. 34 35頁, 愛媛大学耳鼻咽喉科学 教室, 1986 .

9) May MVD : Differential diagnosis by history, physical findings, and Laboratory results. Facial Nerve. pp 181 216, Thieme inc, New York, 1986.

10) Koike $Y$ and Inamura $H$ : Effects of early administration of high-dose steroids on Bell's palsy. The Facial Nerve. pp 395 400, Kugler and Ghedini publications, Amstelveen, 1990.
11) Inamura $H$, Aoyagi $M$, Tojima $H$, et al : Effects of acyclovir in Ramsay Hunt syndrome. Acta Otolaryngol (Stochk) suppl 446 : 113 116, 1988.

12）武田一彦, 戸島 均, 稲村博雄, 他: ハント症 候群に対するステロイド大量投与とアシクロヴ ィルの併用効果について. Facial N Jpn $9: 177$ $\sim 180,1990$.

$$
\left(\begin{array}{l}
\text { 別刷請求先 : 戸島 均 } \\
\text { 厂990-23 山形市飯田西2-2-2 } \\
\text { 山形大学医学部耳鼻咽喉科学教室 }
\end{array}\right)
$$

